\title{
Movement of Four Satellite-Monitored Polar Bears in Lancaster Sound, Northwest Territories
}

\author{
R.E. SCHWEINSBURG ${ }^{1}$ and L.J. LEE ${ }^{1}$
}

\begin{abstract}
Four female polar bears, fitted with satellite-monitored transmitters at Lancaster Sound, N.W.T. during May 1979, were tracked to determine seasonal distribution, movements relative to ice conditions, and home range. Most locations $(68.7 \%, n=46)$ of satellite-tracked bears were on landfast ice, $13.4 \%(n=9)$ on old pack ice, $13.4 \%(n=9)$ on land, $3.0 \%(n=2)$ on bergy water, and $1.5 \%(n=$ 1) on young pack ice. These observations support the conclusions of mark-recapture studies in the area, that landfast ice is favored until breakup when bears move onto land. Data from the satellite-tracked bears indicate that they had home ranges.
\end{abstract}

Key words: polar bear, telemetry, satellite

RÉSUMÉ. Une observation de quatre ours blancs pourvus de transmetteurs à repérage par satellite fut effectuée au détroit de Lancaster, dans les T. N.-O., en mai 1979, afin de déterminer leur distribution saisonnière, leurs mouvements par rapport aux conditions des glaces et leur domaine individuel. La plupart des localisations $(68,7 \%, n=46)$ des ours étaient sur la banquise côtière, $13,4 \%(n=9)$ sur de la vieille banquise, $13,4 \%(n=9)$ sur terre ferme, $3,0 \%(n=2)$ dans des eaux comblées d'icebergs et $1,5 \%(n=1)$ sur de la jeune banquise. Ces observations appuient les conclusions des études par marquage et recapture dans la région selon lesquelles la banquise côtière est favorisée jusqu'au déglacement, période à laquelle les ours se rendent sur terre ferme. Les données obtenues des ours suivis par satellite laissent savoir qu'ils se déplaçaient à l'intérieur de leurs domaines individuels.

Mots clés: ours blanc, télémesure, satellite

Traduit pour le journal par Maurice Guibord.

\section{INTRODUCTION}

Exploratory drilling for oil and natural gas has been proposed for Lancaster Sound and Baffin Bay, Northwest Territories. Ecologists have expressed concern about the exploration because of the perceived hazards of drilling in such a biologically rich area as Lancaster Sound (Milne and Smiley, 1978). Hence a joint industry-government study was initiated in 1978 to gather information about the fauna as a basis for an overall environmental impact assessment for the area (Eastern Arctic Marine Environmental Study [EAMES]; Sutterlin, 1982).

The polar bear (Ursus maritimus Phipps) occupies the upper trophic level in most arctic marine food chains and as such was included for study by EAMES. Distribution, movement and abundance studies of polar bears were initiated in 1978, the results of which were reported in Schweinsburg et al. (1982).

The ways in which polar bear distributions change in response to ice conditions are particularly important in areas vulnerable to oil spills. The logistic difficulties of trying to track polar bears in all seasons with conventional telemetry methods prevented a complete understanding of year-round polar bear movements and habitat use. However, recent advances in satellite telemetry (Koltz et al., 1978) allow tracking of polar bears throughout the year. In 1979, we fitted four bears with satellite transmitters and this paper reports the results of the tracking.

The main objectives of the satellite telemetry study were to (1) gather information on polar bear seasonal use of ice types and landforms, and (2) provide supplementary information on movements and home ranges. A secondary objective was to evaluate the use of satellite telemetry as a technique for studying polar bears.

\section{STUDY AREA}

The land surrounding Lancaster Sound and Baffin Bay is high and mountainous with cliffs, ice fields, glaciers, and fiords along most of the coastline (Dunbar and Greenaway, 1956). Winter is severe at this latitude $\left(74^{\circ} \mathrm{N}\right)$ with average temperatures of less than $-30^{\circ} \mathrm{C}$ in February; yearly precipitation is about $13 \mathrm{~cm}$, much of which is snow. Spring and autumn are almost nonexistent, and summer is defined as the period of open water.

General descriptions of the study area and ice patterns are given in Schweinsburg et al. (1982), but a more detailed description of ice patterns during 1979 is presented here in the context of the movements of the transmitter-marked bears. The first ice map (Fig. 1-A; Ice Forecasting CentralOttawa, 1979) in 1979 was not available until 12 June (bears were fitted with satellite collars during the early part of May). On 12 June there was bergy water (open water with no sea ice but with icebergs present) from the mouth of Jones Sound to the mouth of Lancaster Sound; the remainder of the study area was mostly ice-covered. By 10 July the north part of Baffin Bay was open (Fig. 1-B), and by 7 August the entire study area consisted of unconsolidated ice or bergy water (Fig. 1-C). During September, open water prevailed (Fig. 1-D); by 16 October, freeze-up was underway (Fig. 1-E) and by 30 October the study area was again covered with ice (Fig. 1-F). The last

'Wildlife Service, Government of the Northwest Territories, Yellowknife, N.W.T., Canada X1A 2L9 

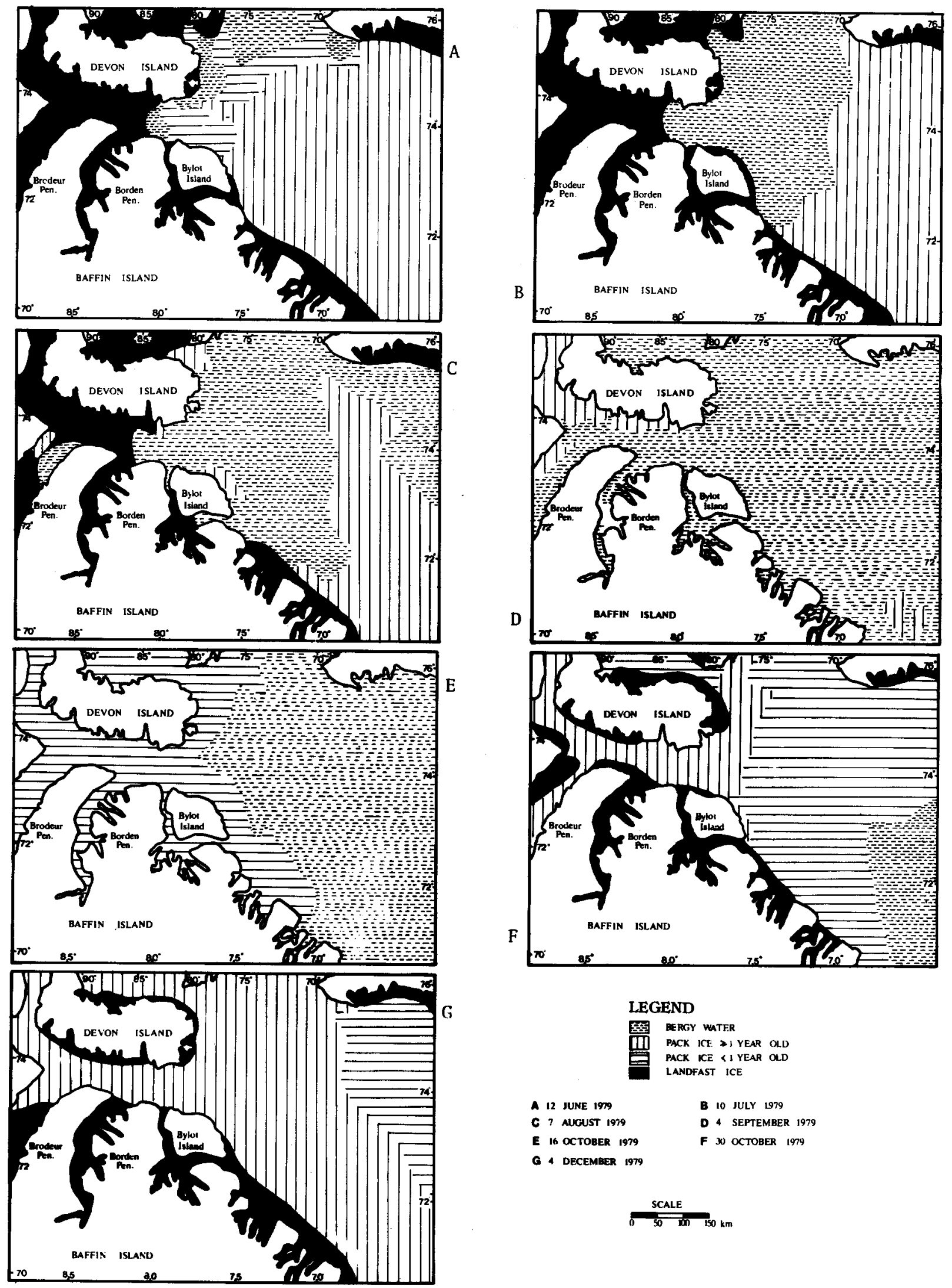

\section{LEGEND}

国 BERGY WATER

III PACK ICE $\rightarrow 1$ YEAR OLD PACK KCE $<1$ YEAR OLD
LANDFAST ICE

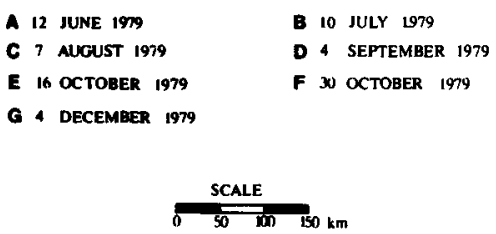

FIG. 1. Ice conditions in the study area, June-December, 1979. 
ice map available for 1979 was for 4 December (Fig. 1-G). At that time, the ice had congealed in a pattern that probably lasted until the following breakup. Although the general pattern of ice breakup and formation was similar to that of 1971 (Ice Forecasting Central-Ottawa, 1971), the ice in Lancaster Sound was much heavier in 1979 than during the mid-1970s (Smith and Rigby, 1981).

\section{MATERIALS AND METHODS}

The National Aeronautics and Space Administration operated the NIMBUS VI satellite, which was designed to collect meteorological and oceanographic data from transmitters throughout the world. The U.S. Fish and Wildlife Service was authorized to track polar bears with this system, and under their aegis the Northwest Territories Wildlife Service placed satellite transmitters on four polar bears in and near Lancaster Sound.

In May 1979, four adult female polar bears were located by helicopter, immobilized (Lentfer, 1968; Larsen, 1971) and fitted with satellite transmitters (Handar Inc., Santa Clara, CA.; Table 1). The units were designed to transmit once every four days and standard RF telemetry transmitters were included in the collars to allow short-range tracking from aircraft. The transmitter collars were held on the bears by harnesses of stainless steel aircraft cable covered by heavy rubber tubing. A corrosive link ensured that each harness would be shed after about 15 months. The harness, collar and transmitter operation were described in detail by Taylor (1981).

To determine home range size, we measured the minimum convex polygon area (Mohr, 1947) for each successive location using the Apple II computer graphics tablet. The observation-area curve (Odum and Kuenzler, 1955) was then plotted and the asymptote was used as an estimate of home range size.

Irregular transmissions were received over a period from May 1979 to June 1980 (Table 1). Although the transmitters were designed to transmit eight hours once every four days, several problems significantly reduced the number of positions we had anticipated receiving. The time period during which the satellite was able to "see" the active transmitter was only 24 minutes. If the timing of the collar transmission and that of the satellite over-pass were not synchronized, no communication would occur. Also, if the bear was on its side, in the water, or behind a land mass, the likelihood of a good transmission was reduced. The system was capable of calculating a transmitter's positions with an accuracy of $\pm 5 \mathrm{~km}$ (Koltz et al., 1978) but gave two readings, one on each side of the satellite

TABLE 1. Information about the four female polar bears fitted with satellite-monitored tracking transmitters during 1979

\begin{tabular}{|c|c|c|c|c|c|c|c|}
\hline $\begin{array}{c}\text { Bear } \\
\text { Number }\end{array}$ & $\begin{array}{l}\text { Age of bear } \\
\text { in years }\end{array}$ & $\begin{array}{l}\text { Number of } \\
\text { cubs of } \\
\text { the year }\end{array}$ & $\begin{array}{l}\text { Date captured } \\
\text { recaptured }^{\mathrm{b}} \text { or } \\
\text { resighted }^{\mathrm{c}}\end{array}$ & $\begin{array}{c}\text { Dated fitted } \\
\text { with } \\
\text { transmitter }\end{array}$ & $\begin{array}{l}\text { Number of } \\
\text { location } \\
\text { points, } \\
\text { satellite and } \\
\text { (other) }\end{array}$ & $\begin{array}{c}\text { Date } \\
\text { transmitter } \\
\text { became } \\
\text { stationary }\end{array}$ & $\begin{array}{c}\text { Date } \\
\text { transmission } \\
\text { ended }\end{array}$ \\
\hline 441 & 6 & 1 & 2 May $79^{a}$ & 2 May 79 & $12(1)$ & 26 January 80 & 8 June 80 \\
\hline 451 & 4 & 2 & $\begin{array}{l}20 \text { August } 75^{a} \\
3 \text { May } 79^{b}\end{array}$ & 3 May 79 & $26(2)$ & 27 December 79 & 30 May 80 \\
\hline 346 & 5 & 0 & $\begin{array}{r}27 \text { April } 78^{a} \\
28 \text { April } 78^{c} \\
29 \text { April } 78^{c} \\
7 \text { May } 79^{b} \\
11 \text { May } 79^{c} \\
16 \text { May } 79^{c} \\
30 \text { April } 80^{b} \\
4 \text { May } 80^{\circ} \\
8 \text { May } 80^{\circ}\end{array}$ & 7 May 79 & $11(9)$ & 15 June 79 & 15 June 79 \\
\hline 465 & 17 & $\mathbf{0}$ & $\begin{array}{r}7 \text { May } 79^{a} \\
12 \text { May } 79^{b} \\
13 \text { May } 79^{c} \\
19 \text { May } 79^{c}\end{array}$ & 12 May 79 & $2(4)$ & 13 September 79 & 13 September 79 \\
\hline
\end{tabular}


orbit. Therefore, judgment was in some cases required to select the "true" reading. Premature loss of transmitters because of harness failure was also significant and reduced the overall effectiveness of the technique.

Some of the bears were resighted up to two weeks after being fitted with a transmitter (Table 1) but none were sighted after that. We assumed that transmitters were on the bears and reflected real movements until the location of the bears stopped changing.

\section{RESULTS}

\section{Movements of Bear \#441}

Bear \#441 was fitted with a transmitter near the north shore of Bylot Island during early May 1979 (Fig. 2); she was accompanied by one cub-of-the-year. Signals were received near the northeast coast of Bylot Island until early July when the signals moved southwest, reaching Eclipse Sound by early August and Bernier Bay by September. The bear then moved north during the period of freeze-up along the coast of Brodeur Peninsula. The signals finally became stationary at the mouth of Admiralty Inlet during late January and we assume the harness broke and the transmitter was lost.

There are two probable movement paths for bear \#441 between 3 August and 28 September, the period for which we have no location fixes; along the coast of Borden Peninsula or overland to Bernier Bay. We consider it much more likely that the latter route was followed because: (1) the signals show a continual southwest movement; (2) bears often come onto land at this time of year, eat vegetation and hunt geese and other birds (Jonkel et al., 1970; Schweinsburg et al., 1982; Russell, 1975); and (3) the wet sedge valleys of lower Borden Peninsula are bird breeding areas. It is possible that the bear intentionally used the

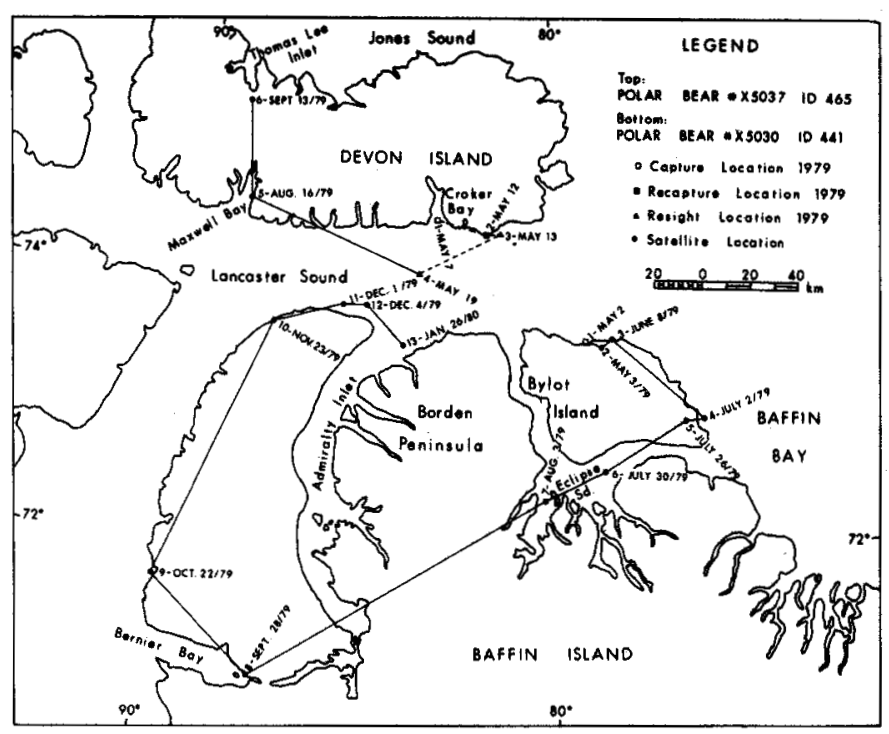

FIG. 2. Satellite-monitored movements of polar bears 441 and 465 . drainage connection between Eclipse Sound and Admiralty Inlet as bears use the well-known Polar Bear Pass (Nettleship and Smith, 1975; see also movements of bear \#465).

The movement north during October-December was probably along the ice edge as the ice formed and seal hunting again became possible. The movement east along the south coast of Lancaster Sound suggests a return to Bylot Island. Over a period of nine months this bear was always located within $20 \mathrm{~km}$ from shore and all fixes were on land or landfast ice.

\section{Movements of Bear \#451}

Bear \#451 was a cub-of-the-year when first captured during August 1975 at the northwest corner of Bylot Island. She was recaptured in May 1979 (accompanied by two cubs-of-the-year) approximately $35 \mathrm{~km}$ northwest of Buchan Gulf, Baffin Island and was fitted with a transmitter (Fig. 3). During May and early June the bear spent time at the mouth of Pond Inlet, but then moved offshore about $130 \mathrm{~km}$ into Baffin Bay during late June and early July. She returned to landfast ice during mid-July and stayed at least until mid-August on or near a small coastal island. The bear spent the remainder of the tracking period on or along the coast around Buchan Gulf. Locations did not change after 27 December 1979 and we assumed the transmitter had fallen off. The RF transmitter signal was picked up during a helicopter search in mid-May 1980 in the Buchan Gulf area, but the transmitter could not be found.

In contrast to the dramatic movements of \#441, this bear remained for an extended period of time in one general area. The offshore foray of this bear during late June and early July apparently was along the edge of pack ice and bergy water in northeast Baffin Bay (Figs. 1-B and 3).

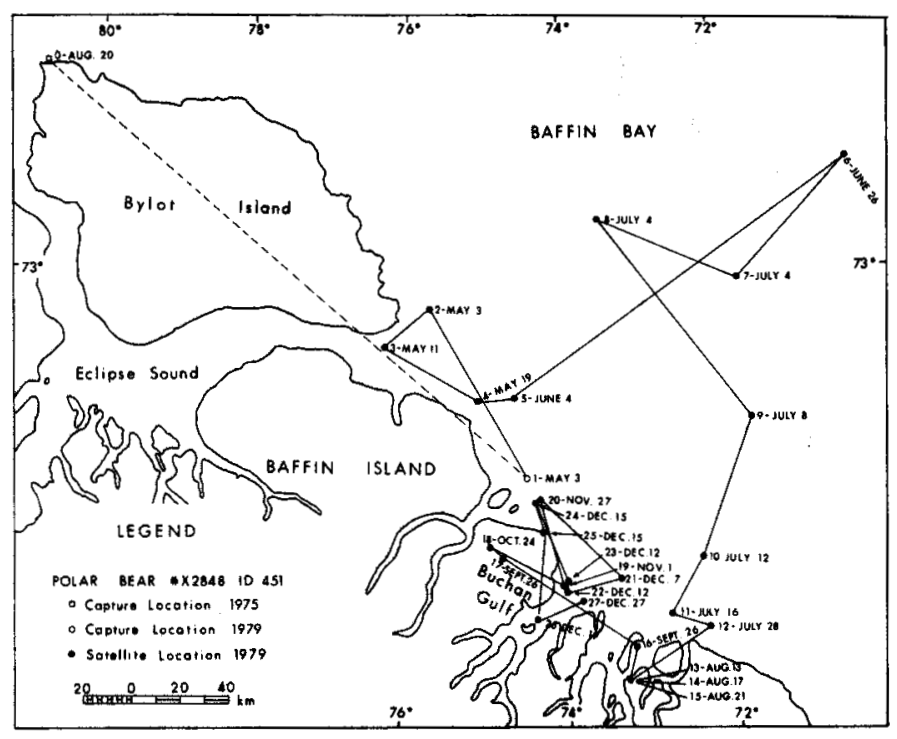

FIG. 3. Satellite-monitored movements of polar bear 451 . 
Ringed seals, including young, have been reported on the offshore pack ice in this area of Baffin Bay during early July and polar bears have been recorded up to $250 \mathrm{~km}$ offshore of northeast Baffin Island (Koski and Davis, 1979).

\section{Movements of Bear \#346}

This bear was captured near Croker Bay in 1978 and resighted twice in the same area. In 1979, it was resighted twice at the mouth of Croker Bay after being fitted with a transmitter. All position fixes from the satellite were in the same general area until transmission ceased on 15 June 1979(Fig. 4). At this time, we assumed that the transmitter had fallen off the bear, but it could have been lost earlier. The variation in position might have been caused by the variable resolution of the tracking system. The bear was recaptured a year later without the transmitter, again in Croker Bay.

The capture and tracking history of this bear shows a seasonal fidelity to a relatively small area. Croker Bay has a relatively high bear density (pers. obs.) and it was apparently an important late winter (April-May) area for bear \#346 during the course of its capture history. Croker Bay is also known to be a summer retreat for polar bears (N.W.T. Wildlife Service Map Series) so there is a possibility that she spent at least the summer if not the entire year there.

\section{Movement of Bear \#465}

This bear was first captured on 12 May 1979 at the mouth of Croker Bay. A week later, she was recaptured near Cape Warrender and fitted with a transmitter (Fig. 2). She was resighted the next day near Cape Warrender, and again six days later $40 \mathrm{~km}$ south of Cape Home. The collar was still in place at that time, but no signal was received

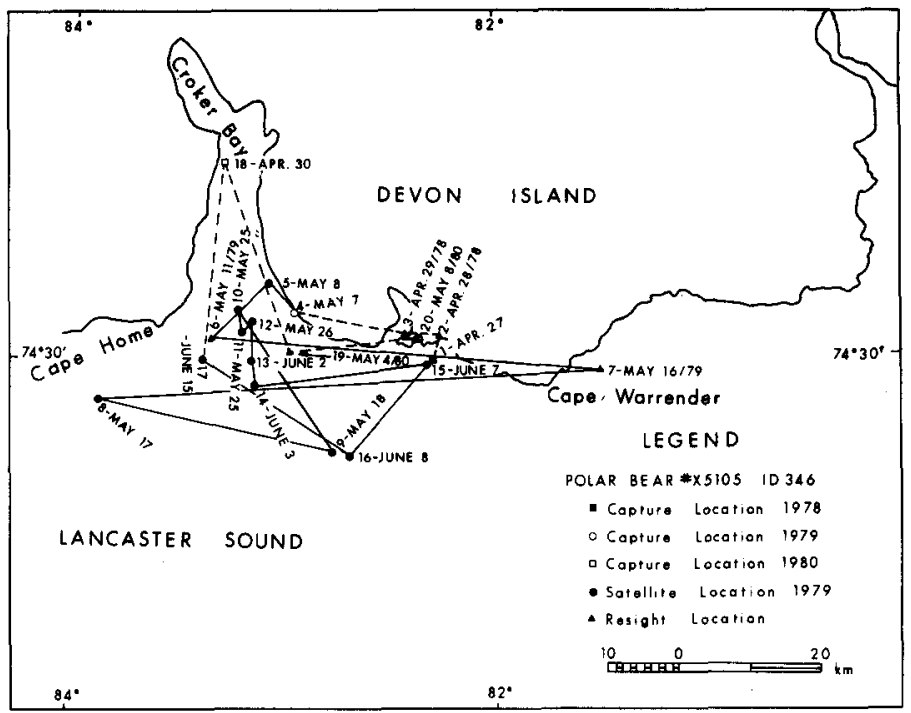

FIG. 4. Satellite-monitored movements of polar bear 346 . until 16 August in Maxwell Bay. The next and last position location was just south of Thomas Lee Inlet, Devon Island, about $76 \mathrm{~km}$ north of Maxwell Bay.

Although this bear was located only a few times, its habitat use was consistent with those of other bears in that most of the positions were near the coast and the bear went on land during the period of minimum ice.

\section{Movements in Relation to Ice and Land}

In this study, $68.7 \%(n=46)$ of the locations of polar bears were on landfast ice, $13.4 \%(n=9)$ on old pack ice, $1.5 \%(n=1)$ on young pack ice, $3.0 \%(n=2)$ on bergy water, and $13.4 \%(n=9)$ on land. It is clear, based on the relatively large available choice of other habitats, that the bears preferred landfast ice. The movements of the satellitemonitored bears were consistent with what had been inferred about polar bear seasonal movements from previous observations and mark-recapture data (Schweinsburg et al., 1982). In general, in areas where there is open water in the summer, bears move onto land or landfast ice along shore and wait for freeze-up. The preferred habitat after freeze-up is landfast ice, particularly near a floe edge. During this study, bears did not cross large water bodies, but they did appear to cross large land masses.

There was no consistent direction to the movements of polar bears during this study although bears \#441 and \#465 moved to the west as breakup proceeded, a pattern also suggested by earlier mark-recapture studies (Schweinsburg et al., 1982). The satellite data could be used to indicate average movement rates over the entire tracking periods, but relocations were too few to analyze on a seasonal basis (Table 2).

\section{Home Range}

The estimate of the area used by polar bears during this study varied from approximately $2300 \mathrm{~km}^{2}$ for bear \#346 to $19300 \mathrm{~km}^{2}$ and $22900 \mathrm{~km}^{2}$ for bears \#441 and \#451 respectively (Fig. 5). We are able to define with confidence only the home range of \#451. The observation area curve for bear \#441 began to asymptote at the point just prior to loss of the collar, but this was not considered sufficient information to conclude that the bear had bounded its home range, particularly in view of the circuitous and nonrepetitive nature of its track. Bears \#465 and \#346 were also not tracked long enough to determine if they exhibited a home range, but the number of recaptures of bear \#346 over three years within a relatively small area indicates that she was not wandering at random.

\section{DISCUSSION AND CONCLUSIONS}

Although several authors have stated or implied that polar bears do not wander at random over the polar ice cap, but are distributed in discrete populations (Løn $\varnothing$, 1970; Jonkel et al., 1970; Larsen, 1971; Manning, 1971; 
TABLE 2. Summary of $1979-80$ movement data from polar bears equipped with satellite transmitters

\begin{tabular}{|c|c|c|c|c|c|}
\hline Bear \# & 441 & 451 & 346 & 465 & All Bears \\
\hline $\begin{array}{l}\text { Number of days of } \\
\text { satellite observation }\end{array}$ & 266 & 242 & 40 & 129 & 677 \\
\hline $\begin{array}{l}\text { Mean number of days } \\
\text { between locations }( \pm \text { SD) }\end{array}$ & $\begin{array}{c}22.2 \pm 18.9 \\
\mathrm{n}=12\end{array}$ & $\begin{array}{c}9.2 \pm 9.3 \\
\mathrm{n}=26\end{array}$ & $\begin{array}{c}3.1 \pm 2.6 \\
\mathrm{n}=13\end{array}$ & $\begin{array}{c}25.8 \pm 36.9 \\
\mathrm{n}=5\end{array}$ & $\begin{array}{c}11.6 \pm 16.5 \\
\mathrm{n}=56\end{array}$ \\
\hline $\begin{array}{l}\text { Total straight-line } \\
\text { distance travelled }(\mathbf{k m})\end{array}$ & 1063 & 1055 & 253 & 363 & 2734 \\
\hline $\begin{array}{l}\text { Mean distance between } \\
\text { consecutive locations }(\mathrm{km})\end{array}$ & $\begin{array}{c}88.6 \pm 89.5 \\
n=12\end{array}$ & $\begin{array}{c}40.6 \pm 37.2 \\
n=26\end{array}$ & $\begin{aligned} 19.4 & \pm 21.2 \\
\mathrm{n} & =13\end{aligned}$ & $\begin{array}{c}72.6 \pm 54.1 \\
n=5\end{array}$ & $\begin{array}{c}48.8 \pm 56.3 \\
\mathrm{n}=56\end{array}$ \\
\hline $\begin{array}{l}\text { Maximum rate of travel between } \\
\text { two consecutive locations ( } \mathrm{km} / \mathrm{day})\end{array}$ & 15.5 & 79.0 & 65.5 & 12.3 & 79 \\
\hline $\begin{array}{l}\text { Mean rate of travel between two } \\
\text { consecutive locations (km/day) }\end{array}$ & $\begin{array}{c}6.8 \pm 5.1 \\
\mathrm{n}=12\end{array}$ & $\begin{array}{c}13.0 \pm 21.6 \\
n=26\end{array}$ & $\begin{array}{l}12.5 \pm 18.6 \\
\mathrm{n}=13\end{array}$ & $\begin{array}{c}6.6 \pm 4.6 \\
n=5\end{array}$ & $\begin{aligned} 8.8 & \pm 15.4 \\
\mathrm{n} & =56\end{aligned}$ \\
\hline $\begin{array}{l}\text { Mean distance from } \\
\text { capture site }(\mathrm{km})\end{array}$ & $\begin{array}{c}176.4 \pm 129.2 \\
\mathrm{n}=12\end{array}$ & $\begin{array}{c}69.1 \pm 39.0 \\
n=26\end{array}$ & $\begin{array}{c}24.4 \pm 9.6 \\
\mathrm{n}=13\end{array}$ & $\begin{array}{l}96.5 \pm 61.7 \\
n=5\end{array}$ & $\begin{array}{c}94.2 \pm 84.6 \\
\mathrm{n}=56\end{array}$ \\
\hline $\begin{array}{l}\text { Maximum distance from } \\
\text { capture site }(\mathrm{km})\end{array}$ & 417 & 186 & 42 & 176 & 417 \\
\hline
\end{tabular}

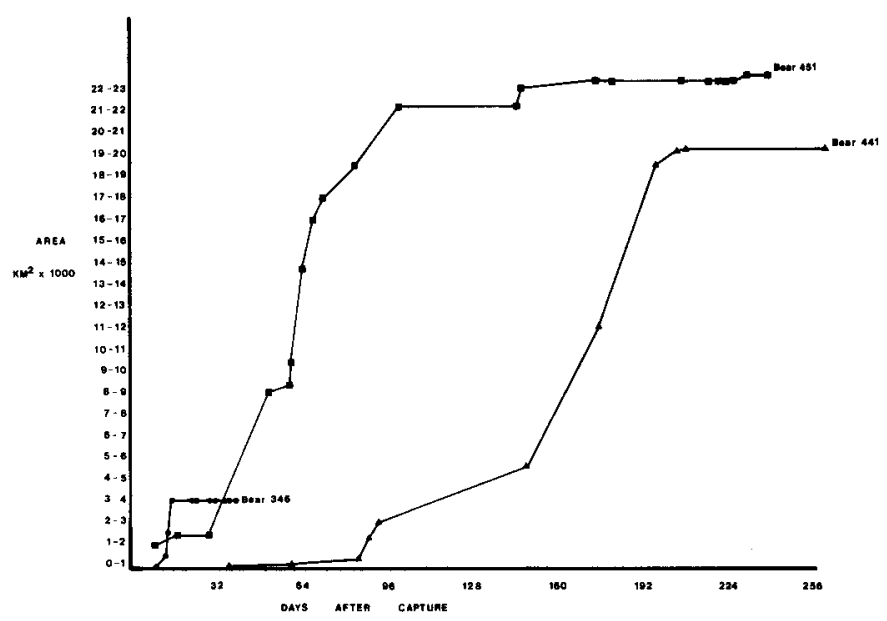

FIG. 5. Observation-area curve for satellite-monitored polar bears.

Lentfer, 1974; Wilson, 1976), none have shown that polar bears have home ranges similar to those of grizzly bears (Pearson, 1975, 1976; Craighead, 1976) and black bears (Piekielek and Burton, 1975; Amstrup and Beecham, 1976; Lindzey and Meslow, 1977). Since other bears and most mammals (Burt, 1943; Sanderson, 1966) display affinity for particular areas, it is likely that polar bears do as well.

Recoveries of marked bears in the N.W.T. (Stirling et al., 1975, 1977, 1978; Schweinsburg etal., 1977; Schweinsburg et al., 1982) suggest that polar bears do have home ranges and results of our satellite tracking support this. The characteristic observation-area curve of an animal utilizing a home range was demonstrated for two of the bears tracked by satellite (Fig. 5) and the three-year seasonal fidelity exhibited by \#346 would seem to indicate that the movements of individual female polar bears in this area of the Canadian Archipelago are geographically restricted.

Yet unexplained, because of small sample sizes, are the occasional long distances travelled by some marked polar bears (Schweinsburg et al., 1982). These could be exploratory movements, or movements related to food scarcity (Stirling et al., 1975) resulting in an expanded lifetime range (Craighead, 1976). Because of extreme yearly ice variations, polar bears may have to be more responsive than other bears to intermittent scarcities of food. Nevertheless, we predict that improvements in satellite-animal telemetry will reveal that polar bears occupy home ranges in the Canadian Archipelago, and that long movements are in response to the above or some yet-to-be-identified factors.

Polar bears tracked by satellite in the Greenland Sea (Taylor, 1981) moved approximately twice as far as they did in the Canadian Archipelago. However, they were only tracked for a few months and more data are needed before this information can be fully interpreted. Polar bear home ranges are probably largest and the bears smallest where food is scarce. Therefore, we speculate that home ranges are largest in the Greenland Sea, where bears are 
the smallest, and smallest in the Chukchi Sea where bears are the largest (Manning, 1971).

As pointed out by Sanderson (1966) the size and shape of home ranges are more meaningful when considered in the context of other ecological information. In this study, female polar bears seemed to prefer the shorefast ice. Stirling and Smith (1975) stated that most seal kills are on offshore ice (as opposed to bay ice) but they did not distinguish between offshore moving and landfast ice. Stirling and Archibald (1977) reported that most seals are killed on "completely frozen ice" (i.e. landfast ice) and fewer on pack ice or the floe edge. McLaren (1958) found mature seals closest to shore whereas sub-adults were forced to occupy the edge of landfast ice. Stirling and Archibald (1977) and Smith (1980) said that pups and sub-adult seals form the largest proportion of the seal kill by polar bears, presumably because they are less experienced and hence easier prey. Therefore, we assume that landfast ice was favoured by polar bears because seals are most easily caught there. Unfortunately, the resolution of our technique (Koltz et al., 1978) was not adequate to tell us whether bears concentrated their activities along the floe edge or elsewhere on landfast ice. We suspect that the edge between landfast ice and moving ice is most important to polar bears.

Although land areas were used only during the time of open water they are probably important in the life histories of polar bears. Until the ice returns, such areas provide platforms, shelter (Jonkel etal., 1970; Schweinsburg, 1979) and food, though most bears probably have sufficient energy reserves to live through this period without eating. Living on stored fat during a period of little food availability is consistent with the pattern observed for the family Ursidae in general. Summer retreat land areas in Lancaster Sound are possibly used more by female and sub-adult bears than by adult males (Schweinsburg et al., 1977). Reasons for this are unknown, but females, particularly those accompanied by cubs, and smaller bears may remain closer to land because of the difficulties of moving through broken offshore ice, or to avoid cannibalistic large male bears. From this study, we could not determine if cubs affected the size of a female's home range.

In other species of bears, females have smaller home ranges than males (Jonkel and Cowan, 1971; Pearson, 1975). However, Schweinsburg et al. (1982) found no differences by sex in lengths of movements of marked polar bears during late winter, possibly because their sampling occurred during the breeding season when males and females were together. Further telemetry studies will help define any sexually related differences in home range size.

Finally, we feel that satellite telemetry is the most promising technique yet developed for studying movements, home and population ranges, and habitat use of polar bears, but technical improvements are required to fully realize its potential. Miniaturization and better attachment systems would greatly improve the technique.

\section{ACKNOWLEDGEMENTS}

Funding for this study was provided by Petro-Canada Explorations Limited; some logistic support was donated by the Polar Continental Shelf Project. We appreciate the field assistance of B. Bergman, M. Taylor and P. Latour of the N.W.T. Wildlife Service. Special thanks go to Dr. D. DeMaster and U.S. Fish and Wildlife Service for their cooperation in obtaining the satellite transmitters and coordinating the data collections. S. Buckles, Apex Helicopters Ltd. and G. Webb and L. Dean, Kenting Helicopters, provided professional and efficient helicopter service. W. Calvert and D. Andriashek of the Canadian Wildlife Service and A. Sutherland of the N.W.T. Wildlife Service did the lab analysis. Dr. I. Stirling of the Canadian Wildlife Service provided advice and back-up support. N. Barichello, K. Lloyd, D. Heard and Dr. I. Stirling reviewed and improved the manuscript.

\section{REFERENCES}

AMSTRUP, S.C. and BEECHAM, J. 1976. Activity patterns of radiocollared black bears in Idaho. Journal of Wildlife Management 40(2):340-348.

BURT, W.H. 1943. Territoriality and home range concepts as applied to mammals. Journal of Mammalogy 24(3):346-352.

CRAIGHEAD, F.C., Jr. 1976. Grizzly bear ranges and movements as determined by radiotracking. In: Bears-Their Biology and Management. Morges, Switzerland: IUCN Publications New Series No. 40. 97-109.

DUNBAR, M. and GREENAWAY, K.R. 1956. Arctic Canada from the Air. Ottawa: Queen's Printer. 541 p.

ICE FORECASTING CENTRAL. 1971. Ottawa, Ontario K1A 0H3. 1979. Ottawa, Ontario K1A 0H3.

JONKEL, C.J., KOLENOSKY, G.B., ROBERTSON, R.J. and RUSSELL, R.H. 1970. Further notes on polar bear denning habits. In: Bears-Their Biology and Management. Morges, Switzerland: IUCN Publications New Series No. 23. 142-158.

JONKEL, C.J. and McTAGGART COWAN, I. 1971. The black bear in the spruce-fir forest. Wildlife Monographs No. $27.57 \mathrm{p}$.

KOLTZ, A.L., LENTFER, J.W. and FALLEK, H.G. 1978. Polar bear tracking via satellite. Proceedings, 15th Annual Rocky Mountain Bioengineering Symposium, Ames, lowa. 137-144.

KOSKI, W.R. and DAVIS, R.A. 1979. Distribution of marine mammals in northwest Baffin Bay and adjacent water, May-October 1978. LGL Ltd. Report to Petro-Canada Ltd., Calgary, Alberta. 305 p.

LARSEN, T. 1971. Capturing, handling and marking polar bears in Svalbard. Journal of Wildlife Management 35(1):27-36.

LENTFER, J.W. 1968. A technique for immobilizing and marking polar bears. Journal of Wildlife Management 32:317-321.

1974. Discreteness of Alaskan polar bear populations. Proceedings of the 11th International Congress of Game Biologists, Stockholm, 3-7 September 1973. 323-329.

LINDZEY, F.G. and MESLOW, E.C. 1977. Home range and habitat use by black bears in southwestern Washington. Journal of Wildlife Management 41(3):413-425.

LøNø, O. 1970. The polar bear in the Svalbard area. Norsk Polarinstitutt Skrifter NR-149. $102 \mathrm{p}$.

McLAREN, I.A. 1958. The biology of the ringed seal in the eastern Canadian Arctic. Bulletin of the Fisheries Research Board of Canada $118.97 \mathrm{p}$.

MANNING, T.H. 1971. Geographical variation in the polar bear. Canadian Wildlife Service Report Series Number 13. Ottawa, Ontario. 27 p.

MILNE, A.R. and SMILEY, B.D. 1978. Offshore drilling in Lancaster Sound, possible environmental hazards. Institute of Ocean Sciences, Patricia Bay, Department of Fisheries and Environment, Sidney, B.C. 95 p.

MOHR, C.O. 1947. Table of equivalent populations of North American small animals. American Midland Naturalist 37(1):223-249. 
NETTLESHIP, D.N. and SMITH, P.A. 1975. Ecological sites in northem Canada. Canadian Committee for the IBP-Conservation TerrestrialPanel 9. Ottawa: Canadian Wildlife Service. $330 \mathrm{p}$.

NORTHWEST TERRITORIES MAP SERIES of Important Polar Bear Habitats. Yellowknife: N.W.T. Wildlife Service. [Available from Wildlife Service, Government of the N.W.T., Yellowknife, N.W.T., Canada.]

ODUM, E.P. and KUENZLER, E.J. 1955. Measurement of territory and home range size in birds. Auk 72:128-137.

PEARSON, A.M. 1975. The northern interior grizzly bear. Canadian Wildlife Service Report Series Number 34. 86 p.

1976. Population characteristics of the arctic mountain grizzly bear. In: Bears-Their Biology and Management. Morges, Switzerland: ICUN Publications New Series No. 40. 247-260.

PEIKIELEK, W. and BURTON, T. 1975, A black bear population study in northern California. California Fish and Game 61(1):4-25.

RUSSELL, R.H. 1975. The food habits of polar bears of James Bay and southwest Hudson Bay in summer and autumn. Arctic 28(2):117-129.

SANDERSON, G.C. 1966. The study of mammal movements - a review Journal of Wildlife Management 30(1):215-235.

SCHWEINSBURG, R.E. 1979. Summer snow dens used by polar bears in the Canadian High Arctic. Arctic 32(2):165-169.

STIRLING, I., OOSENBRUG, S. and KILIAAN, H. 1977. A status report on polar bear studies in Lancaster Sound. Northwest Territories Wildlife Service Report to Norlands Petroleums Ltd. 82 p. [Available from Wildlife Service. Government of the N.W.T., Yellowknife, N.W.T., Canada.]

SCHWEINSBURG, R.E., LEE, J. and LATOUR, P. 1982. Distribution, movements and abundance of polar bears in Lancaster Sound, N.W.T. Arctic 35(1):159-169.

SMITH, M. and RIGBY, B. 1981. Distribution of polynyas in the Canadian Arctic. In: Stirling, I. and Cleator, H. (eds.). Polynyas in the
Canadian Arctic. Canadian Wildlife Service Occasional Paper Number $45.73 \mathrm{p}$.

SMITH, T.G. 1980. Polar bear predation of ringed and bearded seals in the land-fast sea ice habitat. Canadian Journal of Zoology 58:2201-2209.

STIRLING, 1. and ARCHIBALD, W.R. 1977. Aspects of predation of seals by polar bears. Journal of the Fisheries Research Board of Canada 34:1126-1129.

STIRLING, I. , ANDRIASHEK, D., LATOUR, P and CALVERT, W 1975. The distribution and abundance of polar bears in the eastern Beaufort Sea. Final Report to the Beaufort Sea Project. Ottawa: Ministry of Fisheries and Environment. $59 \mathrm{p}$.

STIRLING, I., JONKEL, C., SMITH, P., ROBERTSON, R. and CROSS D. 1977. The ecology of the polar bear along the western coast of Hudson Bay. Canadian Wildlife Service Occasional Paper Number $33.64 \mathrm{p}$.

STIRLING, I., SCHWEINSBURG, R., CALVERT, W. and KILIAAN, H. 1978. Population ecology of the polar bear along the proposed Arctic Islands Gas Pipeline Route. ESCOM Report Number A1-24. Ottawa: Ministry of Indian and Northern Affairs. 93 p.

STIRLING, I. and SMITH, T. 1975. Interrelationships of Arctic Ocean mammals in the sea ice habitat. In: Circumpolar Conference on Northern Ecology, Ottawa, September 1975. Ottawa: Natural Resources Council of Canada 11:131-136.

SUTTERLIN, N. (ed.). 1982. Eastern Arctic Marine Environmental Studies. Arctic 35(1):1-240.

TAYLOR, M. 1981. Summary of satellite radio tracking polar bears with the NIMBUS VI. Random access measurement system. Proceedings, ARGOS User Conference, 28-29 October 1981, San Francisco.

WILSON, D.E. 1976. Cranial variation in polar bears. In: Bears-Their Biology and Management. Morges, Switzerland: ICUN Publications New Series No. 40. 447-453. 